УДК 336.761:336.764

Кривов'язюк I.В., к.е.н., професор

Професор кафедри підприємництва, торгівлі та логістики

Kryvovyazyuk I., PhD in Economics, Professor

Professor of the Department of Entrepreneurship, Trade and Stock Exchange Activity https://orcid.org/0000-0002-8801-4700

\title{
СТАГНАЦІЯ БІРЖОВОГО РИНКУ ЦІННИХ ПАПЕРІВ УКРАЇНИ: ЧИ Є ПЕРСПЕКТИВИ ЗРОСТАННЯ?
}

\author{
Луц̧ький національний технічний університет
}

В статті на основі результатів порівняльного аналізу динамізму розвитку ринку цінних паперів України та його ключової складової - біржового ринку, уточнено тенденції та визначено напрями іiі подальшого розвитку. Підкреслено роль біржового ринку цінних паперів у розвитку економіки країни 3 позицій його впливу на різні сфери діяльності та функціонального призначення. За результатами критичного аналізу наукових праць економістів і фінансистів сучасності у сфері вивчення проблем функціонування фондових ринків країн уточнено коло питань, які заслуговують першочергової уваги з позицій виявлення проблемного характеру їх розвитку та активізації біржової діяльності. Розкрито причини низьхідної динаміки та стагнації розвитку ринку цінних паперів України з позиції міжнародної онлайн-платформи Trading Economics в період 2010-2020 pp. Визначено тенденції зміни обсягів біржової торгівлі на ринку цінних паперів України порівняно 3 динамікою ВВП шляхом розрахунку часткового показника впливовості на його динаміку в період 2015-2020 pр. Наведені порівняльні дані обсягів біржової та позабіржової торгівлі на ринку цінних паперів України виявили тенденцію зміни акцентів торгівлі 3 позабіржового ринку на організовані ринки цінних паперів. Встановлено, що сучасний біржовий ринок цінних паперів України тяжіє до поліцентричної моделі, основу якої становлять ФБ “Перспектива” та ФБ “ПФТС”, на які у досліджуваному періоді припадає 91,94-99,67\% біржового обороту, що вказує на процеси консолідації торгівлі цінними паперами на такому ринку. Аналіз ситуації на біржовому ринку цінних паперів України в період поширення COVID-19 (січень-вересень 2020 р.) виявив, що у досліджуваному періоді порівняно з аналогічним періодом 2019 р. обсяги торгівлі зросли на 3,14\%, і це вказує на відсутність впливу пандемії на динаміку розгортання біржової торгівлі фондовими цінностями. Разом 3 тим, причиною таких змін можна вважати й значне попереднє падіння вітчизняного біржового ринку та його поступове відновлення, яке мало б швидші темпи зростання, якби не вплив поширення COVID-19. Також слід відзначити низьку активність біржовиків на первинному ринку цінних паперів, та відносно високу на вторинному ринку, де предметом торгів найчастіше виступали ОВДП, а торгівля була поширена на спотовому ринку. Вихід зі стану стагнації є можливим за умов, якщо Національна комісія 3 цінних паперів та фондового ринку буде дотримуватись Стратегії розвитку фінансового сектору України до 2025 року, світовий фінансовий ринок буде позбавлений потрясінь, аналогічних лютого-березня 2020 р., матиме місце консолідований розвиток фінансово-інвестиційного, організаційно-правового та соціально значимого забезпечення біржової діяльності країни.

Ключові слова: біржовий ринок, стагнація, цінні папери, біржова торгівля, контракти з цінними паперами, тенденщї розвитку біржової торгівлі, Украӥна.

\section{STAGNATION OF THE STOCK SECURITIES MARKET OF UKRAINE: ARE THERE PROSPECTS FOR GROWTH?}

\author{
Lutsk National Technical University
}

In the article based on the results of comparative analysis of the dynamism of the securities market of Ukraine and its key component - the stock market, the trends are clarified and the directions of its further development are determined. The role of the stock market in the development of the country's economy from the standpoint of its impact on various areas of activity and functional purpose is emphasized. According to the results of critical analysis of scientific works of modern economists and financiers in the field of studying the problems of stock markets functioning, the range of issues that deserve priority attention from the standpoint of identifying the problematic nature of their development and intensification of exchange activities are specified. The reasons for the downward dynamics and stagnation of development of the securities market of Ukraine from the standpoint of the international online platform Trading Economics in the period 2010-2020 are revealed. The tendencies of change of 
volumes of exchange trade in the securities market of Ukraine in comparison with dynamics of GDP by calculation of a partial indicator of influence on its dynamics in the period of 2015-2020 are defined. The presented comparative data on the volume of exchange and over-the-counter trade in the securities market of Ukraine revealed a tendency to change the focus of trade from the over-the-counter market to organized securities markets. It is established that the modern stock market of securities of Ukraine tends to a polycentric model, which is based on FB "Perspective" and FB "PFTS", which in the study period accounted for 91.94-99.67\% of exchange turnover, which indicates the processes of consolidation of securities trade in such a market. Analysis of the situation on the stock market of securities of Ukraine during the spread of COVID-19 (January-September 2020) revealed that in the study period compared to the same period in 2019 , trading volumes increased by $3.14 \%$, and this indicates a lack of pandemy impact on the dynamics of exchange trade in stock values. At the same time, the reason for such changes can be considered a significant previous decline in the domestic stock market and its gradual recovery, which would have had a faster growth rate, if not for the impact of the spread of COVID-19. It should also be noted the low activity of stockbrokers in the primary securities market, and relatively high in the secondary market, where Domestic government bonds were the most frequently traded, and trading was widespread in the spot market. Exit from the state of stagnation is possible if the National Commission on Securities and Stock Market adheres to the Strategy for the Development of the Financial Sector of Ukraine until 2025, the global financial market will be free of shocks similar to February-March 2020, there will be consolidated development of financial investment, organizational, legal and socially significant support of the country's exchange activities.

Key words: stock market, stagnation, securities, stock trading, securities contracts, stock trade development trends, Ukraine.

Постановка проблеми у загальному вигляді та ії зв'язок 3 важливими науковими та практичними завданнями. Біржовий ринок цінних паперів відіграє важливу роль у розвитку економіки країни, адже сприяє зростанню обсягів інвестування, вказуючи на найбільш вигідні об'єкти вкладання капіталу, є сприятливим середовищем розвитку інфраструктури ринку капіталів, й ринку цінних паперів зокрема, позитивно впливає на розвиток ринку послуг (інвестиційного консультування, управління портфелями цінних паперів, розрахунково-клірингових операцій). Одночасно він виконує й такі важливі функції як розміщення державних цінних паперів, сприяння перерозподілу капіталу між сферами бізнесу, виконує функції економічного стабілізатора, що вбудовано в механізм товарно-грошових відносин та при цьому сприяє тривалому і динамічному розвитку господарського механізму, виступає як економічний барометр ділової активності тощо.

Разом 3 тим, український біржовий ринок цінних паперів після обнадійливого 2014 р., коли обсяги торгів становили 619,7 млрд грн, в подальшому суттєво скоротив свої показники та, як показує статистика, перебуває у стані депресії: у 2015 р. обсяги торгів цінними паперами на ньому становили 286,21 млрд грн, у 2016 р. - 235,4 млрд грн, 2017 p. - 205,79 млрд грн, 2018 р. - 260,87 млрд грн, 2019 р. - 304,97 млрд грн, 2020 р. 239,07 млрд грн (станом на 01.10.2020). Супутніми проблемами є скорочення кількості організаторів торгівлі на ринку цінних паперів, професійних учасників, які забезпечують їх діяльність, загальний занепад ринку цінних паперів України.

Стратегією розвитку фінансового ринку України до 2025 року в якості пріоритетів визначено збільшення обсягів інвестування та реформування інфраструктури ринку капіталів, зокрема й біржової. Зростання біржового ринку цінних паперів України $\epsilon$ важливим практичним завданням, що сприятиме покращенню інвестиційної привабливості економіки та здатне забезпечити збільшення надходжень до державного бюджету.

Аналіз останніх досліджень і публікацій, в яких започатковано вирішення проблеми. Дослідженням теоретико-методичних i прикладних засад розвитку фондового та біржового ринку України займалось багато вітчизняних науковців. Зокрема, Н. Дегтярьова, Д. Леонов, В. Січевлюк розкрили загальні засади організації торгівлі на фондовому ринку [1]. О. Калівошко приділив увагу питанням оцінки функціонування та розкриття ролі фондових бірж у розвитку фінансово-кредитного 
ринку України [2]. О. Корнелюк та В. Хірова визначили теоретичну та практичну сутність поняття “біржова криза" та проаналізували передумови та причини сучасного біржового краху 2020 р. [3]. О. Мельник та І. Капітан здійснили порівняльний аналіз найбільших бірж світу та українських бірж за показниками капіталізації, а також виділили загальні проблеми та тенденції функціонування ринку цінних паперів України [4]. В роботах В. Павлова [5-7] розкрито передумови формування ринку цінних паперів України та особливості функціонування фондових бірж. А. Пєхота узагальнив проблеми та пріоритетні напрями модернізації біржової торгівлі України в сучасних умовах господарювання [8]. Н. Рєзнік та А. Остапчук проаналізували особливості функціонування фондового ринку України, а також обгрунтовали основні напрями його удосконалення [9]. Такі вчені як О. Третякова, В. Харабара та Р. Грешко проаналізували біржову структуру та основних організаторів торгівлі на фондовому ринку, визначили проблемний характер функціонування біржового ринку цінних паперів України [10]. Тотожня проблематика розкрита й в наукових дослідженнях В. Базилевича, В. Шелудько, В. Вірченко [11] та Л. Штефан й Н. Мацедонська [12]. До основних висновків, отриманих авторами слід віднести те, що біржовий ринок нині характеризують тенденції зниження обсягів торгівлі, активності учасників біржових торгів, для вирішення економічних проблем держава активно використовує розміщення через біржі випусків державних облігацій, проте й вони не відповідають запитам економіки. Разом з тим, більш глибоких досліджень на сучасному етапі розвитку біржового ринку України потребує визначення його ролі у розвитку ринку цінних паперів, динаміки змін в умовах поширення COVID19, доведення факту, що він перебуває у стані стагнації, узагальнення та прогнозування перспектив його розвитку.

Мета статті полягає в уточненні тенденцій та визначені напрямів подальшого розвитку біржового ринку цінних паперів України.

Виклад основного матеріалу дослідження 3 повним обгрунтуванням отриманих наукових результатів. Ринок цінних паперів України, невід'ємною складовою якого виступає і біржовий ринок, в останнє десятиліття переживає нелегкі часи, та сприймається світовою спільнотою як ринок з дуже низькою інвестиційною привабливістю, без особливих перспектив зростання (рис. 1).

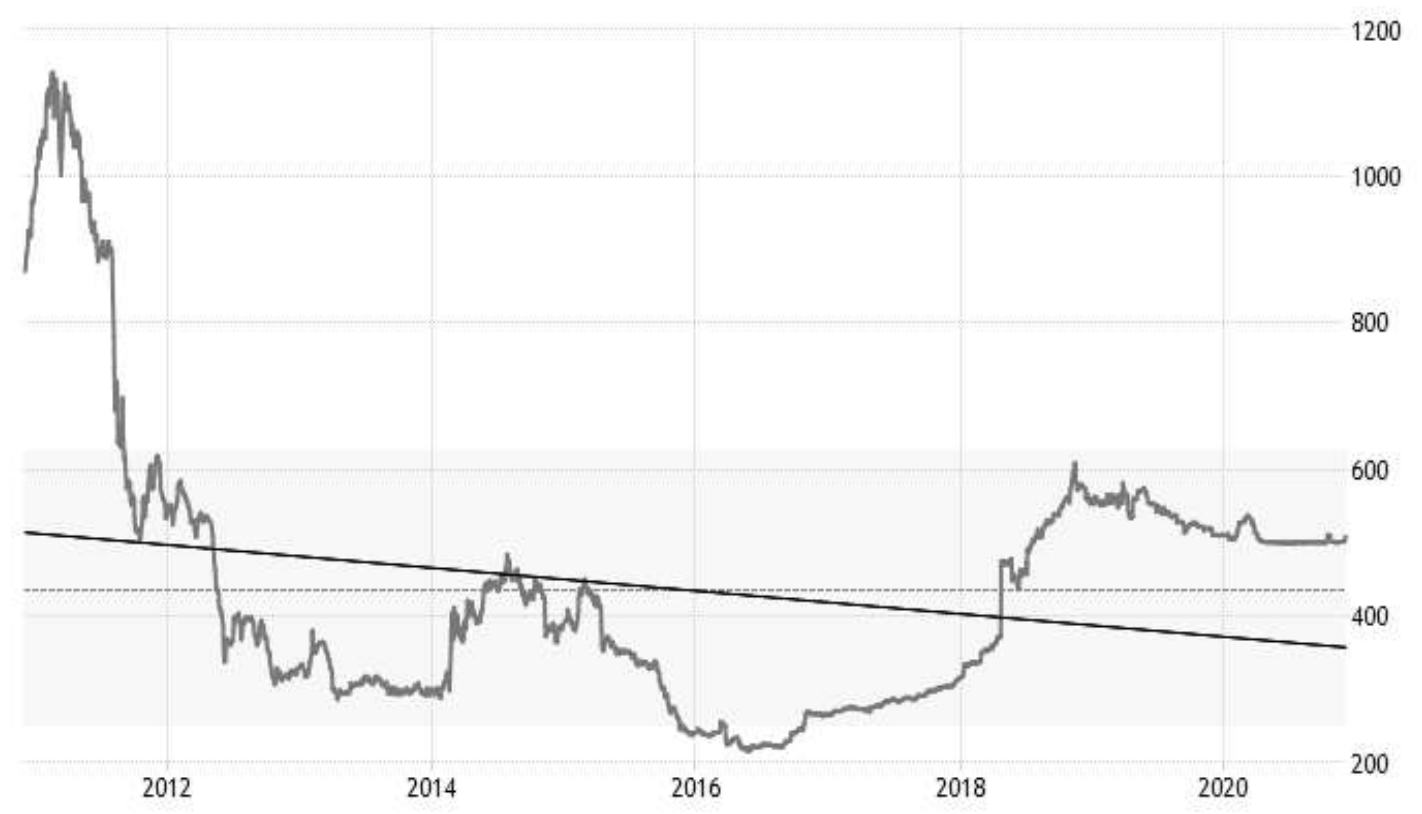

Рис. 1. Динаміка розвитку ринку цінних паперів України з позиції міжнародної онлайн-платформи Trading Economics [13] 
Такий застій зумовлено незадовільним фінансово-економічним становищем i низькою кредитною спроможністю країни, низькою ліквідністю цінних паперів, які котируються на фондових біржах, маніпулюванням цінами на фондовому ринку, проблемним розвитком ринків базових активів, низький рівень фінансової спроможності пересічних громадян тощо. Відтак, зовнішні інвестори та рейтингові агенції не сприймають український фондовий ринок в якості перспективного, а цінні папери вітчизняних компаній - як надійні та вигідні капіталовкладення, навіть, незважаючи на той факт, що у 2018-2019 рр. вітчизняний ринок цінних паперів став найбільш швидко зростаючим у світі.

Сучасний біржовий ринок цінних паперів України розвивається вкрай нестабільно, його співвідношення з обсягами ВВП країни постійно змінюється (рис. 2).

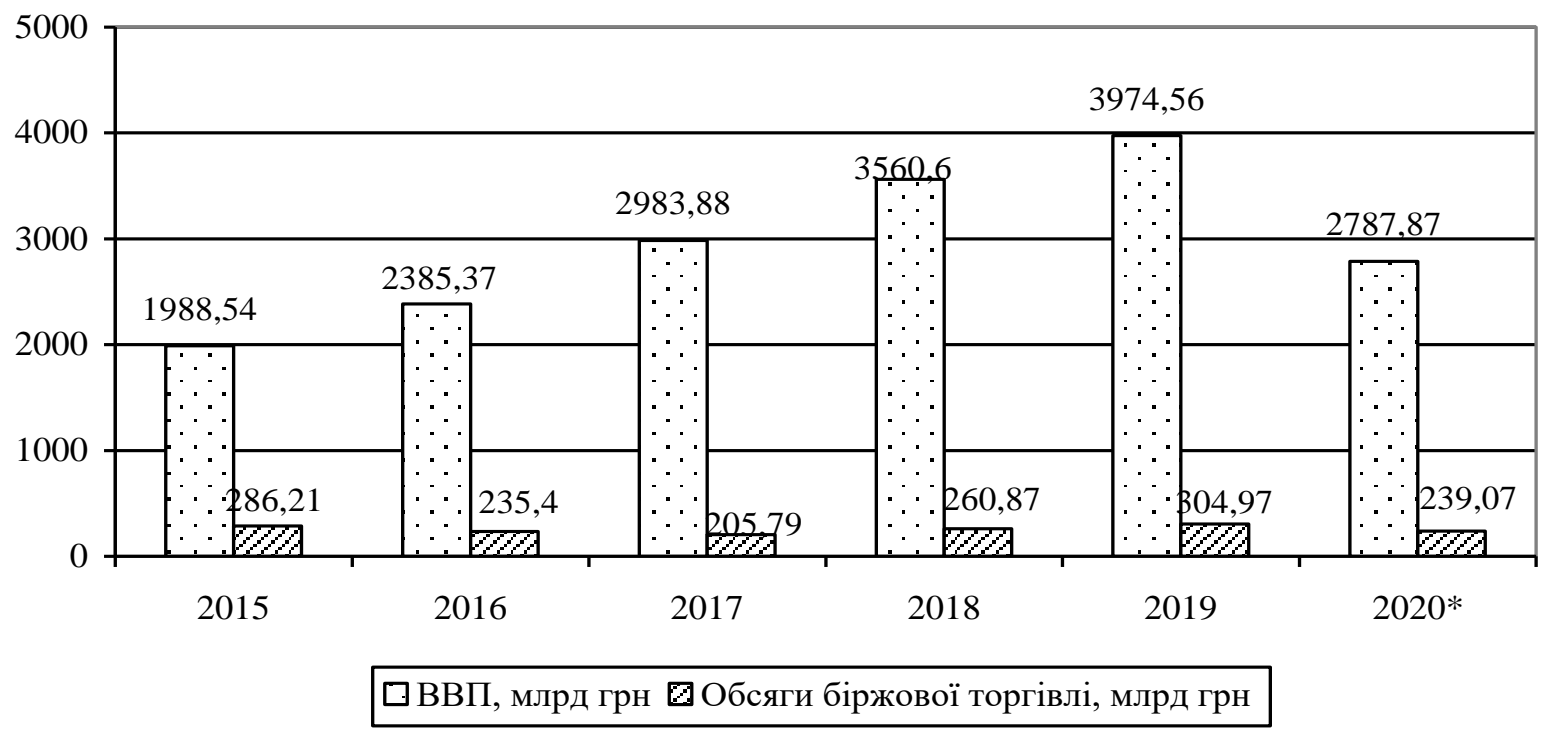

Примітка. 2020* - дані за I-III квартали поточного року.

Рис. 2. Порівняльні дані обсягів біржової торгівлі на ринку цінних паперів і ВВП України $[14 ; 15 ; 16]$

Так, у 2015 р. частка обсягів біржової торгівлі цінними паперами від обсягу ВВП країни становила 14,39\%, 2016 р. - 9,87\%, 2017 р. - 6,90\%, 2018 р. - 7,33\%, 2019 р. 7,67\%, 2020 p. - 8,58\% (за підсумками I-III кварталів поточного року). Результати дослідження вказують, що інвестиційні потоки в реальний сектор економіки поступово відновлюють позитивну динаміку, проте це відбувається досить повільно і існуючий рівень показника не досяг й рівня 2016 р. Зрозуміло, це зайвий раз вказує на низьку інвестиційну привабливість фондового ринку та української економіки в цілому.

Загалом слід констатувати відсутність суттєвих змін обсягів біржової торгівлі на ринку цінних паперів України в період 2015-2020 рр. після його зростання в період 20122014 рр., проте зі сторони Національної комісії з цінних паперів та фондового ринку проведено значну роботу щодо переведення торгівлі 3 позабіржового ринку на організовані ринки цінних паперів. На це вказують дані рис. 3.

В досліджуваному періоді співвідношення між обсягами біржового та позабіржового ринків цінних паперів змінювалось наступним чином: у 2015 р. воно становило 13:87, в 2016 р. - 11:89, у 2017 р. - 44:56, в 2018 р. - 44:56, у 2019 р. - 66:34 та в 
2020 р. - 61:39. Для порівняння: питома вага біржового ринку в Японії становить майже 100\%, в США - 75-80\%, Чехії - 40-50\%. Слід відзначити, що змінюючи акценти на розвиток біржового ринку, його основний регулятор - Національна комісія з цінних паперів та фондового ринку України, збільшує нагляд і контроль за ринком, а держава збільшує обсяги державних цінних паперів на вторинному ринку, намагаючись вирішувати бюджетні проблеми через емісію та розміщення державних облігацій на фондових біржах.

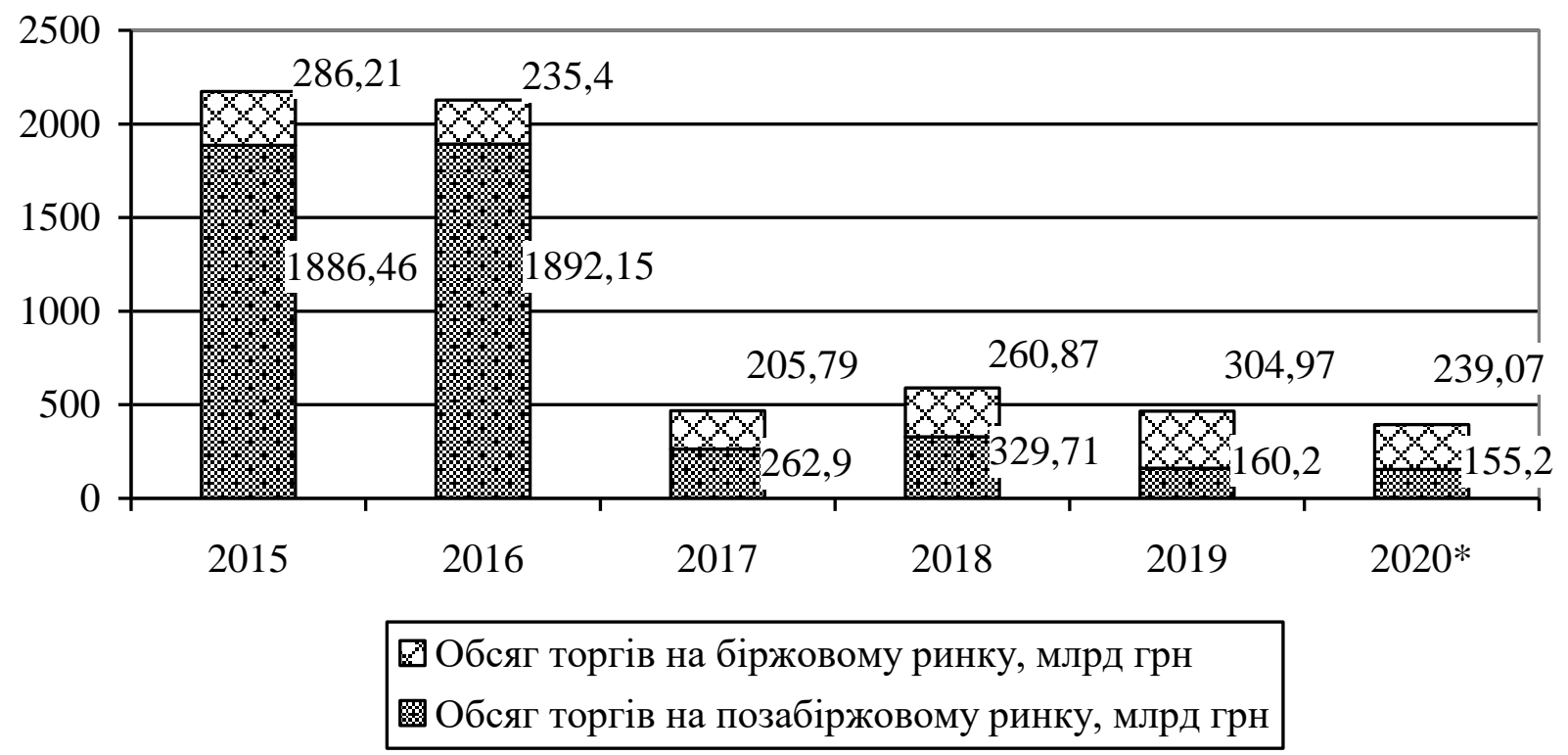

Рис. 3. Порівняльні дані обсягів біржової та позабіржової торгівлі на ринку цінних паперів України $[15 ; 16]$

Біржовий ринок цінних паперів нині тяжіє до поліцентричної моделі, основу функціонування якої становлять декілька потужно функціонуючих бірж. Така модель розвитку біржового ринку сформувалась практично десять років потому. Нині, це дві біржі - ФБ “ПФТС” і ФБ “Перспектива”, частка яких у біржовому обороті становила: 2015 р. 95,56\%, 2016 p. - 97,61\%, 2017 p. - 93,17\%, 2018 p. - 91,94\%, 2019 p. - 98,74\%, 2020 p. 99,67\%. Як результат, прослідковується консолідація торгівлі цінними паперами на зазначених біржах. Додатково слід відмітити зникнення найменш потужних фондових бірж (КМФБ, УНІВЕРСАЛЬНА, СЕФБ, УМВБ, УФБ, ІННЕКС), загальна кількість яких ще в 2015 р. сягала десяти.

Проаналізуємо ситуацію на досліджуваному ринку у період січня-вересня 2020 p. За даними Національної комісії з цінних паперів та фондового ринку, загальний оборот біржових контрактів 3 цінними паперами склав 239 млрд грн. Порівнюючи його 3 аналогічним показником 2019 р. встановлено, що біржовий оборот зріс на 3,14\% (за січень-вересень 2019 р. він складав 231,81 млрд грн). Максимальний оборот з цінними паперами на досліджуваних організаторах торгівлі упродовж аналогічного періоду зафіксовано з ОВДП - 234,7 млрд грн $(98,18 \%$ обсягу біржових контрактів протягом поточного року) (таблиця 1). 
Таблиця 1

Обсяг біржових контрактів з цінними паперами на організаторах торгівлі з розподілом за видом фінансового інструменту в січні-вересні 2020 року, млн грн [16]

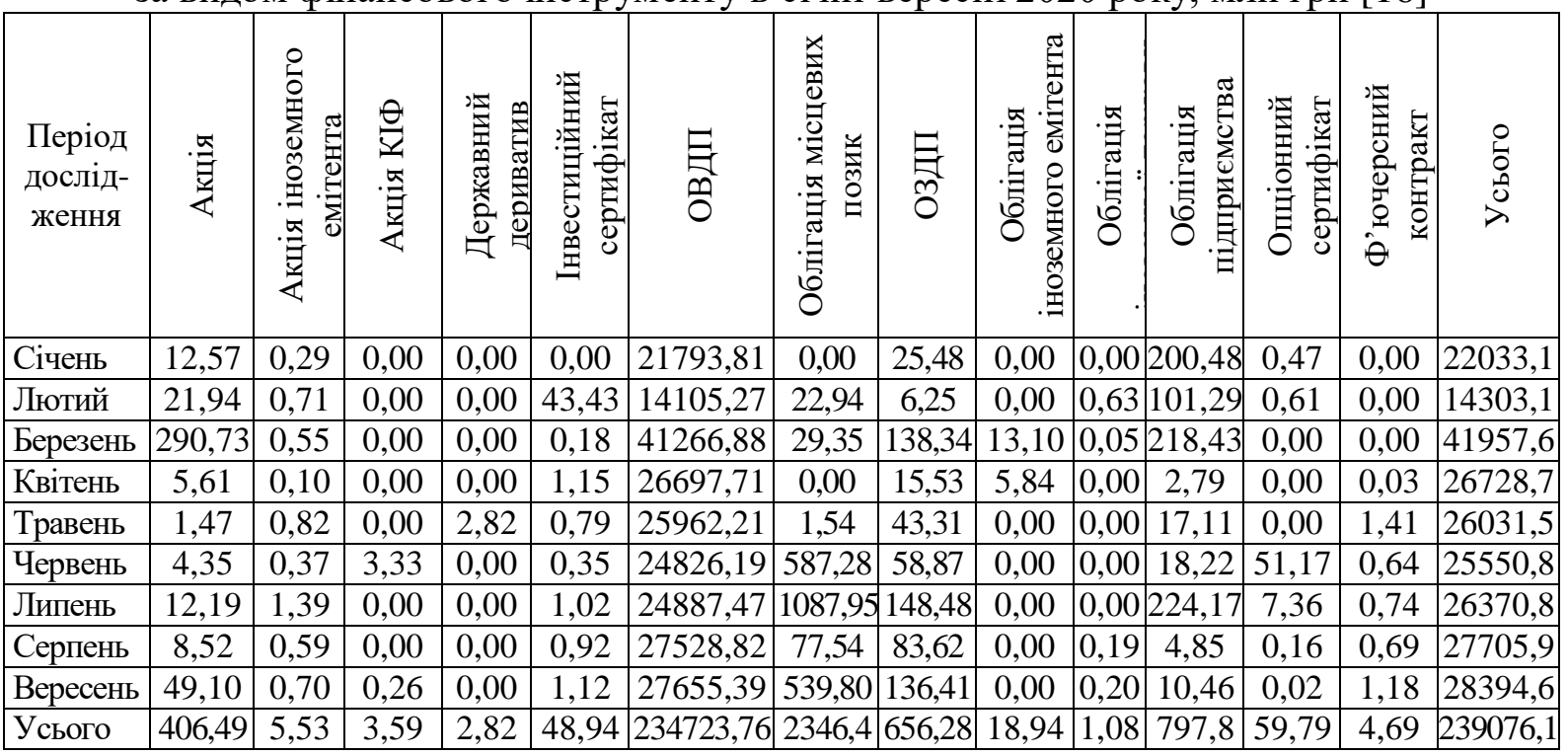

Воднораз, обсяг контрактів з цінними паперами в 2020 році на біржах України на вторинному ринку становив $99,9 \%$ від загального їх обороту упродовж досліджуваного періоду (таблиця 2).

Таблиця 2

Обсяг біржових контрактів з цінними паперами на організаторах торгівлі за видами ринку протягом січня-вересня 2020 року, млн грн [16]

\begin{tabular}{|c|c|c|c|c|c|c|c|}
\hline \multirow[b]{2}{*}{ Фондові біржі } & \multicolumn{2}{|c|}{ Первинний ринок } & \multicolumn{4}{|c|}{ Вторинний ринок } & \multirow[b]{2}{*}{ Усього } \\
\hline & $\begin{array}{c}\text { Спотовий } \\
\text { ринок }\end{array}$ & $\begin{array}{c}\text { Усього на } \\
\text { первинному } \\
\text { ринку }\end{array}$ & $\begin{array}{l}\text { Ринок } \\
\text { РЕПО }\end{array}$ & $\begin{array}{c}\text { Строковий } \\
\text { ринок }\end{array}$ & $\begin{array}{c}\text { Спотовий } \\
\text { ринок }\end{array}$ & $\begin{array}{c}\text { Усього на } \\
\text { вторинному } \\
\text { ринку }\end{array}$ & \\
\hline УБ & 0,00 & 0,00 & 3,15 & 0,28 & 772,89 & 776,31 & 776,31 \\
\hline ПФТС & 208,02 & 208,02 & 1936,82 & 0,00 & 96030,34 & 97967,17 & 98175,18 \\
\hline УМВБ & 0,00 & 0,00 & 0,00 & 4,41 & 0,00 & 4,41 & 4,41 \\
\hline $\begin{array}{l}\text { ПЕРСПЕКТИВ } \\
\text { А }\end{array}$ & 0,00 & 0,00 & 40389,23 & 0,00 & 99730,99 & 140120,22 & 140120,22 \\
\hline Усього & 208,02 & 208,02 & 42329,20 & 4,69 & 196534,22 & 238868,11 & 239076,13 \\
\hline
\end{tabular}

Отримані результати вказують на доцільність пошуку напрямків розвитку біржового ринку цінних паперів України, що забезпечать його подальше зростання. Зокрема, стратегією розвитку фінансового сектору України до 2025 року передбачено запровадження таких фінансових інструментів і механізмів трансформації боргових зобов'язань в ліквідні активи, що сприятимуть розвитку фінансування та інвестування в економічні процеси, удосконалення системи державного регулювання ринку цінних паперів, приведення ії у відповідність до стандартів Міжнародної організації комісій $з$ цінних паперів, що передбачає підвищення інституційної та фінансової незалежності регулятора вітчизняного ринку цінних паперів, забезпечення повноцінної перебудови та подальшого розвитку біржової, розрахункової та клірингової інфраструктури організованих товарних ринків, покращення роботи посередників фінансового сектору та рейтингових агентств згідно вимог СС [17].

Відповідно до Стратегії розвитку фінансового сектору України слід забезпечити подальший розвиток біржового ринку цінних паперів шляхом активізації впровадження сучасних інформаційно-комунікаційних технологій в діяльності організаторів ринку цінних паперів, стимулювання участі іноземних інвесторів до купівлі акцій державних 
акціонерних компаній із врахуванням негативного досвіду продажу пакету акцій АТ "Мотор Січ" шляхом створення більш дієвих механізмів захисту прав інвесторів, іноземних інвестицій через удосконалення обліку прав власності на цінні папери, розвиток можливостей для котирування іноземних цінних паперів для підвищення іміджу українського біржового ринку, забезпечення ефективності державного регулювання біржової діяльності та фондового ринку в цілому шляхом взаємоузгодження функцій управління Національної комісії з цінних паперів та фондового ринку України.

Висновки. Аналіз тенденцій розвитку біржового ринку цінних паперів України вказує на його відносний депресивний стан, що зумовлено як проблемами розвитку фондового ринку, так і процесами консолідації та укрупнення фондових бірж країни, що відбувалися одночасно з виведенням із обігу так званої “макулатури", тобто цінних паперів, які втратили свою цінність на ринку. Позитивом слід відзначити перенесення акцентів торгівлі з позабіржового ринку на організовані ринки цінних паперів. Також слід відзначити, що інвестиційні потоки в реальний сектор економіки поступово відновлюють позитивну динаміку, а це може вказувати на відновлення позитивної динаміки розвитку біржового ринку.

Перспективи зростання біржового ринку цінних паперів України матимуть місце за умов, що дії Національної комісії з цінних паперів та фондового ринку будуть повною мірою відповідати Стратегії розвитку фінансового сектору України до 2025 року, на світовому фінансовому ринку не буде виникати ситуації дефолту як наслідок поширення впливу COVID-19 на всі сфери бізнесу та діяльність акціонерних компаній, буде забезпечено консолідований розвиток фінансово-інвестиційного, організаційноправового та соціально значимого забезпечення біржової діяльності як механізму стимулювання економічного розвитку країни.

Подальші розвідки та дослідження в напрямку розв'язання проблем розвитку біржового ринку цінних паперів важливо розглядати в контексті векторів розвитку Міжнародних комісій 3 цінних паперів, наявних проблем економіки України та можливостей активізації біржової діяльності із врахуванням викликів сьогодення.

\section{Список бібліографічного опису}

1. Дегтярьова Н. В., Леонов Д. А., Січевлюк В. А. Фондовий ринок в Україні : навч. посібник; за заг. ред. Леонова Д.А. Київ : УІРФР, 2015. $600 \mathrm{c.}$

2. Калівошко О. М. Оцінка функціонування фондових бірж, як елемента інфраструктури фінансово-кредитного ринку України. Ефективна економіка. 2019. № 3. URL: http://www.economy.nayka.com.ua/?op=1\&z=6960 (дата звернення: 13.12.2020).

3. Корнелюк О. А., Хірова В. Ю. Особливості прогнозування сучасних біржових криз. Науковий вісник Херсонського державного університету. Серія: Економічні науки. 2020. № 38. С. 12-17.

4. Мельник О. І., Капітан І. М. Сучасні тенденції розвитку фондового ринку України. Ефективна економіка. 2019. № 11. URL: http://www.economy.nayka.com.ua/?op=1\&z=7462 (дата звернення: 01.12.2020).

5. Павлов В. І., Кривов’язюк І. В. Приватизація державних підприємств : навчальний посібник. Луцьк : Надстир'я, 1998. $180 \mathrm{c}$.

6. Павлов В. І., Кривов'язюк І. В. Ринок цінних паперів в умовах приватизації: регіональний аспект : монографія. Луцьк : Надстир'я, 2002. 160 с.

7. Павлов В. I, Пилипенко І. І., Кривов’язюк І. В. Цінні папери в Україні : навч. посіб. Видання 2-ге, доповнене. Київ : Кондор, 2009. 400 c.

8. Пєхота А. В. Біржова торгівля як пріоритетний напрям модернізації ринку цінних паперів України. БІЗНЕСІНФОРМ. 2018. № 7. С. 216-220.

9. Рєзнік Н. П., Остапчук А. Д. Біржовий фондовий ринок: стан та перспективи розвитку в Україні. Український журнал прикладної економіки. 2018. Том 3. № 4. С. 62-66.

10. Третякова О. В., Харабара В. М., Грешко Р. І. Фондовий ринок України: особливості функціонування в сучасних умовах. Економіка та держава. 2020. № 5. С. 103-107.

11. Фондовий ринок : підручник: у 2 кн. Кн. 1 / В. Д. Базилевич, В. М. Шелудько, В. В. Вірченко та ін.; за ред. В. Д. Базилевича; Київ. нац. ун-т ім. Т. Шевченка. Київ : Знання, 2015. 621 с.

12. Штефан Л. Б., Мацедонська Н. В. Тенденції розвитку біржового ринку цінних паперів в Україні. Інфраструктура ринку. 2020. Випуск 42. С. 338-345.

13. Ukraine Stock Market. URL: https://tradingeconomics.com/ukraine/stock-market (дата звернення: 02.12.2020). 
14. Валовий внутрішній продукт за 2015-2020 pp. / Державна служба статистики України. URL: http://www.ukrstat.gov.ua/ (дата звернення: 14.12.2020).

15. Звіти Національної комісії з цінних паперів та фондового ринку України за 2015-2019 рр. / Національна комісія з цінних паперів та фондового ринку України. Офіційний веб-сайт. URL: https://www.nssmc.gov.ua/about-us/annualreports/ (дата звернення: 14.12.2020).

16. Аналіз ринку. Інформаційні довідки щодо розвитку фондового ринку України протягом 2015-2020 років / Національна комісія 3 цінних паперів та фондового ринку України. Офіційний веб-сайт. URL: https://www.nssmc.gov.ua/news/insights/ (дата звернення: 12.12.2020).

17. Стратегія розвитку фінансового сектору України до 2025 року. Рішення НБУ №1010-рш від 26.12.2019 p. URL: https://bank.gov.ua/ua/about/develop-strategy (дата звернення: 14.12.2020).

\section{References}

1. Dehtyar'ova N.V., Leonov D.A., Sichevlyuk V.A. Fondovyy rynok v Ukrayini : navch. posibnyk; za zah. red. Leonova D.A. Kyyiv : UIRFR, 2015. 600 p. [in Ukrainian].

2. Kalivoshko O.M. Otsinka funktsionuvannya fondovykh birzh, yak elementa infrastruktury finansovo-kredytnoho rynku Ukrayiny. Efektyvna ekonomika, 2019, no. 3. Available at: http://www.economy.nayka.com.ua/?op=1\&z=6960. doi: 10.32702/2307-2105-2019.3.46

3. Kornelyuk O.A., Khirova V.Yu. Osoblyvosti prohnozuvannya suchasnykh birzhovykh kryz. Naukovyy visnyk Khersons'koho derzhavnoho universytetu. Seriya: Ekonomichni nauky, 2020, no. 38, pp. 12-17 [in Ukrainian].

4. Mel'nyk O.I., Kapitan I.M. Suchasni tendentsiyi rozvytku fondovoho rynku Ukrayiny. Efektyvna ekonomika, 2019 , no. 11. Available at: http://www.economy.nayka.com.ua/?op=1\&z=7462. doi: 10.32702/2307-2105-2019.11.58

5. Pavlov V.I., Kryvov"yazyuk I.V. Pryvatyzatsiya derzhavnykh pidpryyemstv. Luts'k, Nadstyr"ya, 1998 . 180 p. [in Ukrainian].

6. Pavlov V.I., Kryvov"yazyuk I.V. Rynok tsinnykh paperiv v umovakh pryvatyzatsiyi: rehional'nyy aspekt. Luts'k, Nadstyr"ya, 2002. 160 p. [in Ukrainian].

7. Pavlov V.I, Pylypenko I.I., Kryvov"yazyuk I.V. Tsinni papery v Ukrayini. Vydannya 2-he, dopovnene. Kyyiv, Kondor, 2009. 400 p. [in Ukrainian].

8. Pyekhota A.V. Birzhova torhivlya yak priorytetnyy napryam modernizatsiyi rynku tsinnykh paperiv Ukrayiny. BIZNESINFORM, 2018, no. 7, pp. 216-220 [in Ukrainian].

9. Ryeznik N.P., Ostapchuk A.D. Birzhovyy fondovyy rynok: stan ta perspektyvy rozvytku v Ukrayini. Ukrayins'kyy zhurnal prykladnoyi ekonomiky, 2018, Tom 3, no. 4, pp. 62-66 [in Ukrainian].

10. Tretyakova O.V., Kharabara V.M., Hreshko R.I. Fondovyy rynok Ukrayiny: osoblyvosti funktsionuvannya v suchasnykh umovakh. Ekonomika ta derzhava, 2020, no. 5, pp. 103-107 [in Ukrainian].

11. Fondovyy rynok: u 2 kn. Kn. 1 / V.D. Bazylevych, V.M. Shelud'ko, V.V. Virchenko ta in.; za red. V.D. Bazylevycha; Kyyiv. nats. un-t im. T. Shevchenka. Kyyiv, Znannya, 2015. 621 p. [in Ukrainian].

12. Shtefan L.B., Matsedons'ka N.V. Tendentsiyi rozvytku birzhovoho rynku tsinnykh paperiv v Ukrayini. Infrastruktura rynku, 2020, Vypusk 42, pp. 338-345 [in Ukrainian].

13. Ukraine Stock Market. Available at: https://tradingeconomics.com/ukraine/stock-market (accessed 02.12.2020) [in Ukrainian].

14. Valovyy vnutrishniy produkt za 2015-2020 / Derzhavna sluzhba statystyky Ukrayiny. Available at: http://www.ukrstat.gov.ua/ (accessed 14.12.2020) [in Ukrainian].

15. Zvity Natsional'noyi komisiyi z tsinnykh paperiv ta fondovoho rynku Ukrayiny za 2015-2019 / Natsional'na komisiya z tsinnykh paperiv ta fondovoho rynku Ukrayiny. Ofitsiynyy veb-sayt. Available at: https://www.nssmc.gov.ua/about-us/annualreports/ (accessed 14.12.2020) [in Ukrainian].

16. Analiz rynku. Informatsiyni dovidky shchodo rozvytku fondovoho rynku Ukrayiny protyahom 2015-2020 / Natsional'na komisiya $\mathrm{z}$ tsinnykh paperiv ta fondovoho rynku Ukrayiny. Ofitsiynyy veb-sayt. Available at: https://www.nssmc.gov.ua/news/insights/ (data zvernennya: 12.12.2020) [in Ukrainian].

17. Stratehiya rozvytku finansovoho sektoru Ukrayiny do 2025 roku. Rishennya NBU \#1010-rsh vid 26.12.2019 Available at: https://bank.gov.ua/ua/about/develop-strategy (accessed 14.12.2020) [in Ukrainian].

Дата подання публікації 18.12.2020 р. 